\section{Nonconventional Additives Leave Onion Yield and Quality Unchanged}

\author{
Erik B.G. Feibert ${ }^{1}$, Clinton C. Shock ${ }^{2}$, and Lamont D. Saunders ${ }^{3}$ \\ Malheur Experiment Station, Oregon State University, 595 Onion Avenue, \\ Ontario, OR 97914
}

Additional index words. Allium cepa, ammonium zinc acetate, cytokinin, humic acid, Norwegian kelp, Ascophyllum nodosum, Botrytis allii, Fusarium oxysporum, Aspergillus niger

\begin{abstract}
Eleven treatments in 1999 and thirteen treatments in 2000 containing single or combined nonconventional additives from eight manufacturers were compared with an untreated check for their effect on onion (Allium cepa L.) yield and quality, and for their economic efficiency. The nonconventional additives were tested at commercial rates using the methods of application provided by the manufacturers. The products were applied to soil, foliage, or both. The treatments, including the check, were incorporated into standard cultural practices for onions. All treatments (with exception of an organic fertilizer treatment), including the check, were fertilized based on soil tests. In both years, none of the products evaluated significantly increased onion yield or quality compared to the untreated check. The organic fertilizer treatment, tested in 1999 only, resulted in significantly lower onion yield and size compared to the check. At the application rates used in this study, most of the products supplied plant nutrients or humic acid in amounts insufficient to expect improvements in crop production.
\end{abstract}

A nonconventional additive can be defined as 1) any nonfertilizer material applied to soil or plants claiming to improve crop production; or 2) a guaranteed fertilizer material which is used in an unconventional manner, such as very small amounts (Kephart, 1993). A total of 466 nonconventional additives were being marketed in the United States in 1992 (Kephart, 1993). There was no published research on over $50 \%$ of these products.

Humus or soil organic matter, can be defined as the fairly stable amorphous brown to black material bearing no trace of the anatomical structure of the material from which it was derived (Russell, 1973). It is well established that humus favorably affects soil physical, chemical and biological properties. Separation of humus from the soil for analytical purposes is done by extraction with sodium hydroxide. Further extraction with acid will separate humic acids. Commercial humic acids are extracted from coal, most commonly leonardite. Humic acid is one of the most common types of nonconventional additive. While humic acids have been shown to increase plant growth in nutrient cultures (Chen and Aviad 1990), field research is scarce and the results are inconsistent. Humic acids increased yield of cotton (Gossypium hirsutum L.) and tomato (Lycoperscion esculentum Mill.) when both soil and foliar applied (Brownell et al., 1987), and improved stands and root weight when

Received for publication 29 Nov. 2001. Accepted for publication 30 May 2002. Oregon State Univ. technical paper no. 11844. We thank the Idaho-Eastern Oregon Onion Committee for financial support for this study. Use of trade names does not imply endorsement of the products named or criticism of similar ones not named.

${ }^{1}$ Senior Faculty Research Assistant.

${ }^{2}$ Professor and Superintendent. E-mail address: Clinton.Shock@orst.edu

${ }^{3}$ Biological Sciences Research Technician. applied as a seed coat to carrots (Daucus carota L.) (Sanders, et al., 1990). The percentage of marketable short-day onions after 4.5 months of storage was increased in 1 out of 2 years by a humic acid product applied as a transplant dip and foliar spray (Boyhan et al., 2001). Soil applied humic acid at 269 $\mathrm{kg} \cdot \mathrm{ha}^{-1}$ resulted in a small yield increase of sweet potato [Ipomoea batatas (L.) Poir.] in only 1 out of 3 years (Crawford et al., 1969). When the humic acid rate was increased to $538 \mathrm{~kg} \cdot \mathrm{ha}^{-1}$, a small yield increase in sweet potato resulted all 3 years. Barley (Hordeum vulgare $\mathrm{L}$.) yield was increased by soil applied humic acid at $50 \mathrm{mg} \cdot \mathrm{kg}^{-1}$ of soil $\left(\approx 224 \mathrm{~kg} \cdot \mathrm{ha}^{-1}\right.$, Ayuso et al., 1997). In the study by Ayuso et al., it made no difference whether the humic acid was applied as sewage sludge, compost, leonardite, or a commercial product extracted from peat.

Other studies show no benefit of humic acid use. Potato (Solanum tuberosum L.) yield was not increased by soil application of humic acid at a commercial rate in six site-years (Rowberry and Collin, 1977). Potato yield increases from humic acid applications at commercial rates were minimal (Seyedbagheri and Thornton, 1995). Corn (Zea mays L.) grain yield was not increased by soil applied humic acid up to 560 $\mathrm{kg} \cdot \mathrm{ha}^{-1}$ in any of 3 years (Lawless et al., 1984). Soil applied humic acid did not increase yield or quality of sunflower (Helianthus annuus L.) (Vasudevan et al., 1997). A commercial humic acid extracted from leonardite applied at a high rate $\left(81,805 \mathrm{~kg} \cdot \mathrm{ha}^{-1}\right)$ significantly increased soil organic matter, but did not increase citrus tree growth or fruit yield (Nemec and Lee, 1992).

Cytokinin, a plant growth regulator that stimulates cell division in plants, is another common nonconventional additive. While cytokinins have been used successfully in tissue culture, results in field tests on crops have been inconsistent. Application of cytokinin or its synthetic analog, kinetin, resulted in increases in yield of grape (Vitis vinifera L.) (Reynolds et al., 1992), kiwi fruit (Actinidia deliciosa (A Chev)] (Antognozzi et al., 1993), and alfalfa (Medicago sativa L.) (Tomkins and Hall, 1991). Application of a synthetic cytokinin to pear resulted in increases in fruit size and yield (Flaishman et al., 2001). The percentage of marketable short-day onions after 4.5 months of storage was increased in one out of two years by a product containing cytokinin applied as a transplant dip and foliar spray (Boyhan et al., 2001). Cytokin increased cotton lint yield by $11 \%$ and $6 \%$ compared to an untreated check, in only two out of seven years (Oosterhuis and Robertson, 2000). Other studies show no benefit from cytokinin use. Hedin and McCarty (1994) found no cotton yield increases from cytokinin application. Cytokinin applied to flowering narrow-leafed lupin (Luninue angustifolius L.) did not increase seed yield (Ma et al., 1998).

The growth promoting effects of marine algae extracts have been attributed to plant hormones including cytokinin (Abetz, 1980). Field test results applying extracts from marine algae on crops have been inconsistent. Eris et al. (1995) found that pepper (Capsicum annum L.) fruit yield was increased by foliar applications of a Norwegian kelp (Ascophyllum nodosum L.) concentrate. Taylor et al. (1990) found no effect of a commercial marine algae extract on barley yield. Likewise two commercial marine algae extracts, tested in 32 field trials over three years, did not increase wheat (Triticum aestivum L.) yield when applied as either seed or foliar treatments (Miers and Perry, 1986).

The Idaho-Eastern Oregon Onion Committee requested that the Malheur Experiment Station test nonconventional additives because onion growers were investing money in these products without knowledge of their effectiveness. The objective of this study was to test the most commonly marketed nonconventional additives for onion production in the Treasure Valley of eastern Oregon and southwestern Idaho at commercial application rates and methods. The products tested can be included in the following descriptive categories: humic acid, Norwegian kelp concentrate, biological inoculant with $\mathrm{N}$-fixing bacteria, plant growth regulators (cytokinin and ammonium zinc acetate), organic fertilizer, and mineral nutrient solutions.

\section{Materials and Methods}

The trials were conducted in 1999 and 2000 at the Malheur Experiment Station on Owyhee silt loam (coarse-silty, mixed, mesic, Xerollic Camborthids). The fields had previously been planted to wheat. Before plowing in Fall 1998, nitrogen (N) at $22 \mathrm{~kg} \cdot \mathrm{ha}^{-1}$ and phosphorus $(\mathrm{P})$ at $44 \mathrm{~kg} \cdot \mathrm{ha}^{-1}$ were broadcast. Before plowing in Fall 1999, N at $22 \mathrm{~kg} \cdot \mathrm{ha}^{-1}, \mathrm{P}$ at $49 \mathrm{~kg} \cdot \mathrm{ha}^{-1}$, $\mathrm{Zn}$ at $11 \mathrm{~kg} \cdot \mathrm{ha}^{-1}$, and $\mathrm{Mg}$ at $34 \mathrm{~kg} \cdot \mathrm{ha}^{-1}$ were broadcast. Each year, the wheat stubble was shredded, and the field was disked, irrigated, moldboard-plowed, roller-harrowed, fumigated with 1,3 dichloropropene at $144 \mathrm{~kg} \cdot \mathrm{ha}^{-1}$ 
and chloropicrin at $6 \mathrm{~kg} \cdot \mathrm{ha}^{-1}$, and bedded. Soil chemical characteristics, determined from a composite soil sample of the top $30 \mathrm{~cm}$ from all check treatment plots taken in mid-May each year, are listed in Table 1.

Dry surface soil was harrowed off the beds on 16 Mar. 1999 and 6 Apr. 2000. Onion seed (cv. Vision; Petoseed, Payette, Idaho) was planted 7 Apr. both years at 378,000 seeds/ha in double rows centered $0.56 \mathrm{~m}$ apart on 1.1 $\mathrm{m}$ beds. Vision is a hybrid full season Spanish long-day onion with relatively high yields and a relatively low incidence of decomposition in storage (Shock et al., 2000). The experimental design was a randomized complete block with six replicates. Plots were $7 \mathrm{~m}$ long and four double rows wide.

The trial was managed to avoid yield reductions from weeds, pests, and diseases. Weeds were controlled with three cultivations in 1999 and two in 2000, and with standard commercial herbicide applications as needed until layby. After layby the field was hand weeded as necessary.

The trial was furrow irrigated to maintain soil water potential at $20 \mathrm{~cm}$ depth above -20
$\mathrm{kPa}$ (Shock et al., 1998). Soil water potential was monitored by six granular matrix sensors (GMS, Watermark Soil Moisture Sensors model 200SS; Irrometer Co., Riverside, Calif.) installed in early June below the onion row at $20 \mathrm{~cm} \mathrm{depth}$. Irrigations were terminated on 24 Aug. each year.

Companies marketing products locally were invited to participate in the trial. Participating companies supplied the treatment protocols (Table 2). Eight companies entered treatments in 1999 and seven companies entered treatments in 2000 (Table 2). Each

Table 1. Soil analyses for 1999 and 2000 nonconventional additive trials for onions.

\begin{tabular}{|c|c|c|c|c|c|c|c|c|c|c|c|c|c|c|}
\hline \multirow[b]{2}{*}{ Year } & \multirow{2}{*}{$\begin{array}{c}\text { Organic matter } \\
(\%)\end{array}$} & \multicolumn{13}{|c|}{ Nutrient analysis $\left(\mathrm{mg} \cdot \mathrm{kg}^{-1}\right)$} \\
\hline & & $\mathrm{pH}$ & $\mathrm{N}$ as $\left(\mathrm{NO}_{3}\right)$ & $\mathrm{P}$ & $\mathrm{K}$ & $\mathrm{Ca}$ & $\mathrm{Mg}$ & $\mathrm{Na}$ & $\mathrm{Zn}$ & $\mathrm{Fe}$ & $\mathrm{Mn}$ & $\mathrm{Cu}$ & $\mathrm{S}$ as $\left(\mathrm{SO}_{4}\right)$ & $\mathrm{B}$ \\
\hline 1999 & 1.5 & 7.3 & 4 & 41 & 404 & 2,685 & 341 & 165 & 1.4 & 12 & 45.6 & 1 & 7 & 0.5 \\
\hline 2000 & 1.6 & 6.9 & 19 & 39 & 526 & 2,080 & 378 & 240 & 0.8 & 9 & 3.8 & 0.5 & 21 & 0.6 \\
\hline
\end{tabular}

Table 2. Nonconventional additives, rates, and application modes tested on onion.

\begin{tabular}{|c|c|c|c|c|}
\hline Treatment & Company $^{2}$ & Products & $\operatorname{Rate}^{\mathrm{y}}\left(\mathrm{L} \cdot \mathrm{ha}^{-1}\right)$ & Application mode \\
\hline \multirow[t]{2}{*}{1} & Ag Concepts Corp. & Jump Start 5-5-5 & 14.0 & in seed furrow \\
\hline & & Jump Start 5-5-5 & 9.4 & 1 st and 2 nd sidedress \\
\hline \multirow[t]{4}{*}{2} & Ag Concepts Corp. & Agzyme & 0.9 & $10 "$ band pre-plant \\
\hline & & Humaide & 0.9 & $10 "$ band pre-plant \\
\hline & & Kelp Treat & 4.7 & $10 "$ band pre-plant \\
\hline & & Jump Start 5-5-5 & 9.4 & 1 st and 2 nd sidedress \\
\hline \multirow[t]{6}{*}{3} & Ag Concepts Corp. & Jump Start 5-5-5 & 9.4 & $10 "$ band pre-plant \\
\hline & & Humaide & 2.3 & $10 "$ band pre-plant \\
\hline & & Kelp Treat & 4.7 & $10 "$ band pre-plant \\
\hline & & Agzyme & 0.5 & 1st sidedress \\
\hline & & Kelp Treat & 2.3 & 2nd sidedress \\
\hline & & Humaide & 2.3 & 3rd sidedress \\
\hline \multirow[t]{2}{*}{4} & Horizon Ag Products & Agri-Plus (1999 only) & $45 \mathrm{~kg}$ & broadcast pre-plant \\
\hline & & Quantum-H & 9.4(1999), 28.0(2000) & in seed furrow, 1 st and 2 nd sidedress \\
\hline 5 & RSA Microtech & RSA Humic acid & 9.4 & in seed furrow, 1 st sidedress \\
\hline \multirow[t]{2}{*}{6} & RSA Microtech ${ }^{x}$ & High Yield & $7.8 \mathrm{~kg}$ & foliar 3 times \\
\hline & & Expand & $0.4^{\circ}$ & foliar 3 times \\
\hline 7 & RSA Microtech ${ }^{x}$ & Expand & 0.4 & foliar 3 times \\
\hline 8 & RSA Microtech ${ }^{x}$ & High Yield & $7.8 \mathrm{~kg}$ & foliar 3 times \\
\hline 9 & Dynamite Marketing ${ }^{\mathrm{w}}$ & Humi-Zyme-RX & $935^{\circ}$ & broadcast pre-plant \\
\hline \multirow[t]{2}{*}{10} & AgriGro & Agrigro & 1.2 (1999), 2.3 (2000) & 10 " band pre-plant \\
\hline & & Agrigro & 1.2 & seed furrow, 1st, 2nd sidedress, foliar $3 X$ \\
\hline \multirow[t]{4}{*}{11} & AgriGro & Agrigro & $1.2(1999), 2.3(2000)$ & $10 "$ band pre-plant \\
\hline & & Agrigro & 1.2 & seed furrow, 1st, 2nd sidedress, foliar $3 \mathrm{X}$ \\
\hline & & Agri-Calcium & 28.0 & $10 "$ band pre-plant \\
\hline & & Agri-Calcium & 18.7 & 1st and 2 nd sidedress \\
\hline \multirow[t]{9}{*}{12} & Huma Grow & Pop-up mix & 28.1 & in seed furrow \\
\hline & & Blend & 2.3 & 1 st and 2 nd sidedress \\
\hline & & Superphos & 4.7 & 1st and 2nd sidedress \\
\hline & & Sulfur & 0.6 & 2nd foliar \\
\hline & & Copper & 0.5 & 3rd foliar \\
\hline & & Calcium & 0.8 & 4th foliar \\
\hline & & Vitol & 2.3 & 1st and 2 nd foliar \\
\hline & & Jackpot (2000 only) & 2.3 & 3 weeks before lifting \\
\hline & & Calcium (2000 only) & 0.8 & 3 weeks before lifting \\
\hline 13 & UAP Northwest & Awaken & 4.7 & in seed furrow \\
\hline \multirow[t]{2}{*}{14} & Kozgrow $^{w}$ & Kozgro & 1.5 & broadcast pre-plant \\
\hline & & Kozgro & 1.2 & 1st and 2nd foliar \\
\hline \multirow[t]{8}{*}{15} & Miller Chemical $^{\mathrm{x}}$ & Calcium & $0.6 \mathrm{~kg}$ & 2 nd foliar \\
\hline & & Calcium & $1.1 \mathrm{~kg}$ & 3rd, 4th foliar \\
\hline & & Cytokin & 1.1 & in seed furrow \\
\hline & & Cytokin & 0.6 & 3rd foliar \\
\hline & & Cytokin & 0.6 & 4th foliar \\
\hline & & Microplex & $1.1 \mathrm{~kg}$ & in seed furrow, 1st foliar \\
\hline & & Microplex & $0.6 \mathrm{~kg}$ & 2 nd foliar \\
\hline & & Nutrient Express & $5.6 \mathrm{~kg}$ & $1 \mathrm{st}, 2 \mathrm{nd}, 3 \mathrm{rd}, 4 \mathrm{th}$ foliar \\
\hline
\end{tabular}

${ }^{2} \mathrm{Ag}$ Concepts Corp., Boise, Idaho; Horizon Ag-Products, Kennewick, Wash.; RSA Microtech, Seattle, Wash.; Dynamite Marketing, Meridian, Idaho; Kozgro, Caldwell, Idaho; Agri-Gro, Doniphan, Mo.; Huma Grow-BioHumanetics, Chandler, Ariz.; UAP Northwest, Caldwell, Idaho; Miller Chemical, Hanover, $\mathrm{Pa}$.

${ }^{\mathrm{y}} \mathrm{All}$ rates in $\mathrm{L} \cdot \mathrm{ha}^{-1}$ except for dry products in $\mathrm{kg} \cdot \mathrm{ha}^{-1}$.

${ }^{x}$ Treatments in 2000 only.

"Treatments in 1999 only. 
treatment consisted of a single product or combination of products. In 2000, treatments 1, 2, $3,5,9,10$, and 12 were the same as in 1999 . Treatment 4 in 2000 was the same as in 1999 except that the granular product Agri-Plus was omitted and the liquid product Quantum-H had the application rate increased to $28 \mathrm{~L} \cdot \mathrm{ha}^{-1}$ per application. Treatment 11 in 2000 was the same as in 1999 except that two additional products were applied 3 weeks before the onions were undercut. Variation in treatments between years was caused by changes in participation by the cooperating companies. An untreated check treatment was included each year.

The product application rates and application modes varied widely among treatments (Table 2), as did the nutrient and humic acid contents of the products (Table 3 ). Applications in the seed furrow were made in solution just after seed drop at $215 \mathrm{~L} \cdot \mathrm{ha}^{-1}$. Banded pre-plant liquid applications were made using a backpack sprayer at $187 \mathrm{~L} \cdot \mathrm{ha}^{-1}$ and $200 \mathrm{kPa}$. Beds were raked off once before pre-plant banded applications were made. Foliar liquid applications were made using a backpack sprayer at $280 \mathrm{~L} \cdot \mathrm{ha}^{-1}$ and $200 \mathrm{kPa}$. Broadcast granular applications were made with a hand-held fertilizer spreader. Sidedressed liquid applications were made to both sides of the bed at 560 $\mathrm{L} \cdot \mathrm{ha}^{-1}$. All sidedressed products were mixed with the $\mathrm{N}$ fertilizer (urea-ammonium nitrate solution, URAN). In 1999, all treatments, including the check, were sidedressed on 7 June and again on 23 June with $\mathrm{N}$ at $112 \mathrm{~kg} \cdot \mathrm{ha}^{-1}$ as URAN, except treatments 6 and 11 . Treatment 6 (Humi-Zyme-RX) did not receive any $\mathrm{N}$ fertilizer. Humi-Zyme-RX is marketed as a complete organic fertilizer and was applied at a rate claimed to provide sufficient $\mathrm{N}$ to the onions. Treatment 11 (Kozgro) received $\mathrm{N}$ at $84 \mathrm{~kg} \cdot \mathrm{ha}^{-1}$ the first sidedressing and at $112 \mathrm{~kg} \cdot \mathrm{ha}^{-1}$ the second sidedressing. In 2000 , all treatments, including the check, were sidedressed with $\mathrm{N}$ at $112 \mathrm{~kg} \cdot \mathrm{ha}^{-1}$ on 26 May and again on 21 June.

The onions were undercut with a rod weeder in mid September each year to field dry. Onions from the middle two rows of every plot were topped and bagged by hand in the field on 28 Sept. 1999 and on 20 Sept. 2000. The onions were placed into storage in late September each year. The storage shed was managed to maintain an air temperature of $\approx 1$ to $4{ }^{\circ} \mathrm{C}$.

Onions were graded out of storage on 30 Nov. each year. Bulbs were separated according to quality: bulbs without blemishes (No. 1s), split bulbs (No. 2s), neck rot (bulbs infected with the fungus Botrytis allii Munn. in the neck or side), plate rot (bulbs infected with the fungus Fusarium oxysporum Schlechtend. Fr. f. sp. cepae (H.N. Hans.) W.C. Snyder \& H.N. Hans.), and black mold (bulbs infected with the fungus Aspergillus niger Tiegh.). The No. 1 bulbs were graded according to diameter: small $(<57 \mathrm{~mm})$, medium (57 to
$76 \mathrm{~mm}$ ), jumbo (77 to $102 \mathrm{~mm}$ ), and colossal (>102 mm).

Onion production costs were based on data prepared by the Malheur County Extension Service. All onion production costs were the same for all treatments except: 1) the treatment product retail cost 2) the estimated product application cost and 3) harvest cost which was based on total yield and included loading and hauling, bin rental and storage, and grower assessments.

In 1999, onion production costs for treatment 6 did not include $\mathrm{N}$ fertilizer, and production costs for treatment 11 had $\mathrm{N}$ fertilizer cost reduced by $12.5 \%$. The treatment production costs were based on the onion production cost plus the retail cost and application cost of the products in each treatment.

Gross economic returns were calculated by crediting each marketable onion class with the average price of onions paid to the grower from the beginning of the marketing season in early August through January. Average prices were calculated for the years 1992 through 2000 from data prepared by the U.S. Dept. of Agriculture, Agricultural Marketing Service, Idaho Falls, Idaho. Prices reflecting adjustments for packing and shipping costs, in U.S. dollars per $\mathrm{Mg}$ averaged over the last 9 years, were: $\$ 89.21$ for medium grade bulbs, $\$ 149.78$ for jumbo grade bulbs, and $\$ 212.12$ for colossal grade bulbs.

Treatment differences were compared

Table 3. Nonconventional additive nutrient and humic acid concentration, product specific gravity, and total amount applied at application rates tested. All concentrations were supplied by the manufacturers. Nutrients present at concentrations of less than a tenth of a percent were not included.

\begin{tabular}{|c|c|c|c|c|c|c|c|c|c|c|c|c|c|c|}
\hline \multirow[b]{2}{*}{ Treatment } & \multirow[b]{2}{*}{ Product } & \multicolumn{10}{|c|}{ Nutrient concentration (\%) } & \multirow{2}{*}{$\begin{array}{c}\text { Humic } \\
\text { acid }(\%)\end{array}$} & \multirow{2}{*}{$\begin{array}{l}\text { Specific } \\
\text { gravity } \\
\left(\mathrm{g} \cdot \mathrm{L}^{-1}\right)\end{array}$} & \multirow{2}{*}{$\begin{array}{c}\text { Total product } \\
\text { applied } \\
\text { per hectare }\end{array}$} \\
\hline & & $\mathrm{N}$ & $\mathrm{P}$ & $\mathrm{K}$ & $\mathrm{Ca}$ & $\mathrm{S}$ & $\mathrm{Mg}$ & $\mathrm{Fe}$ & $\mathrm{Zn}$ & $\mathrm{Mn}$ & $\mathrm{Cu}$ & & & \\
\hline$\overline{1}$ & Jump Start 5-5-5 & 0 & 5 & 5 & --- & --- & --- & --- & --- & --- & --- & 0.5 & 1110 & 32.7 \\
\hline \multirow[t]{4}{*}{2} & Humaide & --- & --- & --- & --- & --- & --- & --- & --- & --- & --- & 1.5 & 1068 & 9.4 \\
\hline & Agzyme & --- & --- & --- & --- & --- & --- & --- & --- & --- & --- & --- & 1032 & 0.8 \\
\hline & Kelp Treat & --- & --- & --- & --- & --- & --- & --- & --- & --- & --- & --- & 1044 & 4.7 \\
\hline & Jump Start 5-5-5 & 5 & 5 & 5 & --- & --- & --- & --- & --- & --- & --- & 0.5 & 1110 & 18.7 \\
\hline \multirow[t]{4}{*}{3} & Jump Start 5-5-5 & 5 & 5 & 5 & --- & --- & --- & --- & --- & --- & --- & 0.5 & 1110 & 9.4 \\
\hline & Humaide & --- & --- & --- & --- & --- & --- & --- & --- & --- & --- & 12 & 1068 & 4.7 \\
\hline & Agzyme & --- & --- & --- & --- & --- & --- & --- & --- & --- & --- & --- & 1032 & 0.4 \\
\hline & Kelp Treat & --- & --- & --- & --- & --- & --- & --- & --- & --- & --- & --- & 1044 & 7 \\
\hline \multirow[t]{2}{*}{$4(1999)$} & Agri-Plus & --- & --- & --- & --- & --- & --- & --- & --- & --- & --- & 70 & --- & 45 \\
\hline & Quantum-H & --- & --- & --- & --- & --- & --- & --- & --- & --- & --- & 6 & 1020 & 28.1 \\
\hline $4(2000)$ & Quantum-H & --- & --- & --- & --- & --- & --- & --- & --- & --- & --- & 6 & 1020 & 84.2 \\
\hline 5 & RSA Humic acid & --- & --- & --- & --- & --- & --- & --- & --- & --- & --- & 12 & 1068 & 18.7 \\
\hline \multirow[t]{2}{*}{6} & High Yield & 15 & 20 & 20 & --- & 2 & --- & 0.1 & 1 & 0.1 & 0.15 & --- & --- & 23.5 \\
\hline & Expand & --- & --- & --- & --- & --- & --- & --- & 0.25 & 0.2 & 0.6 & --- & 1105 & 1.1 \\
\hline 7 & Expand & --- & --- & --- & --- & --- & --- & --- & 0.25 & 0.2 & 0.6 & --- & 1105 & 1.1 \\
\hline 8 & High Yield & 15 & 20 & 20 & --- & 2 & --- & 0.1 & 1 & 0.1 & 0.15 & --- & --- & 23.5 \\
\hline 9 & Humi-Zyme-RX & 4 & 3 & --- & --- & 3 & --- & --- & --- & --- & --- & --- & 1128 & 935.4 \\
\hline 11 & Agri-Calcium & --- & --- & --- & 10 & --- & --- & --- & --- & --- & --- & --- & 1355 & 60.8 \\
\hline \multirow[t]{7}{*}{12} & Pop-up mix & 4.3 & 6.3 & 2.1 & --- & --- & --- & --- & --- & --- & --- & --- & 1064 & 28.1 \\
\hline & Blend & 5 & --- & --- & --- & --- & --- & --- & --- & --- & --- & --- & 1060 & 4.7 \\
\hline & Superphos & --- & 22 & --- & --- & --- & --- & --- & --- & --- & --- & --- & 1522 & 9.4 \\
\hline & Sulfur & 8 & --- & --- & --- & 10 & --- & --- & --- & --- & --- & --- & 1251 & 0.6 \\
\hline & Copper & --- & --- & --- & --- & 4 & --- & --- & --- & --- & 5 & --- & 1140 & 0.4 \\
\hline & Calcium & 7 & --- & --- & 10 & --- & --- & --- & --- & --- & --- & --- & 1360 & 0.8 \\
\hline & Vitol & 8 & 16 & 4 & --- & 1 & --- & --- & --- & --- & --- & --- & 1335 & 4.7 \\
\hline 13 & Awaken & 18 & --- & 2.5 & --- & --- & --- & --- & 2.7 & --- & --- & --- & 1230 & 4.7 \\
\hline \multirow[t]{2}{*}{14} & Kozgro-pre-plant & --- & --- & --- & --- & --- & --- & --- & --- & --- & --- & 3.1 & 1008 & 1.5 \\
\hline & Kozgro-foliar & --- & --- & --- & --- & --- & --- & --- & --- & --- & --- & 3.1 & 1008 & 1.2 \\
\hline \multirow[t]{4}{*}{15} & Microplex (seed furrow) & --- & --- & --- & --- & --- & 5.43 & 4 & 1.5 & 4 & 1.5 & --- & --- & 1.1 \\
\hline & Microplex (foliar) & --- & --- & --- & --- & --- & 5.43 & 4 & 1.5 & 4 & 1.5 & --- & --- & 1.7 \\
\hline & Nutrient Express & 4 & 41 & 27 & --- & --- & --- & --- & --- & --- & --- & --- & --- & 22.4 \\
\hline & Calcium & --- & --- & --- & 9.5 & --- & --- & --- & --- & --- & --- & --- & --- & 23.4 \\
\hline
\end{tabular}

${ }^{z}$ All rates in $\mathrm{L} \cdot \mathrm{ha}^{-1}$ except for dry products in $\mathrm{kg} \cdot \mathrm{ha}^{-1}$ 
using analysis of variance and protected least significant differences (LSD) at the 5\% probability level, $\left(\mathrm{LSD}_{0.05}\right)$.

\section{Results and Discussion}

In 1999, there was no significant difference in plant population (data not shown), plant height (data not shown), onion yield and quality, or profit between any of the treatments and the check, except for treatment 9 (Tables 4 and 5). Treatment 9 (Humi-Zyme-RX) resulted in significantly lower plant height, total yield, marketable yield, colossal onion yield, and profits. The lower productivity of the onions in treatment 9 could have resulted from insufficient $\mathrm{N}$ provided by the Humi-Zyme-RX. Humi-Zyme-RX is marketed as a complete organic fertilizer intended to substitute for conventional fertilizer. Humi-Zyme-RX plots were not fertilized with $\mathrm{N}$ and the HumiZyme-RX supplied a total of $42.1 \mathrm{~kg} \cdot \mathrm{ha}^{-1}$ of $\mathrm{N}$ compared to $224 \mathrm{~kg} \cdot \mathrm{ha}^{-1}$ of $\mathrm{N}$ supplied by the URAN in the check treatment. Based on the mid-May soil tests, the Oregon State Univ. N fertilizer recommendations (Sullivan et al., 2001) were for $\mathrm{N}$ at 209 and 174 $\mathrm{kg} \cdot \mathrm{ha}^{-1}$ in 1999 and 2000, respectively, based on $112 \mathrm{Mg} \cdot \mathrm{ha}^{-1}$ yields, and $168 \mathrm{~kg} \cdot \mathrm{ha}^{-1}$ per year of mineralized $\mathrm{N}$.

In 2000, there were no significant differences in plant population, plant height, onion yield and quality, or profit between any of the treatments and the check (Tables 4 and 5).

With minor exceptions, at the rates tested, the products supplied small amounts of humic acid (Table 6). The results for the products containing humic acid agree with Chen and Aviad (1990) who discuss the improbability that commercial humic acids applied at manufacturers' recommended rates would contain sufficient quantities of the active ingredients to result in improvements in crop production. Chen and Aviad (1990) suggest a minimum of $75 \mathrm{~kg} \cdot \mathrm{ha}^{-1}$ of soil applied humic acid would be necessary for improvement in crop production, based on concentrations of humic substances that are reported to be necessary to affect plant growth in growth chambers. Agri-Plus supplied the highest total amount of humic acid, $31 \mathrm{~kg} \cdot \mathrm{ha}^{-1}$. The other humic acid containing products supplied substantially lower amounts of humic acid. At application rates of $75 \mathrm{~kg} \cdot \mathrm{ha}^{-1}$ of humic acid the liquid products would cost (per hectare): $\$ 612$

Table 4. Onion yield and quality response to nonconventional additives.

\begin{tabular}{|c|c|c|c|c|c|c|c|c|}
\hline \multirow[b]{3}{*}{ Treatment } & \multicolumn{6}{|c|}{ Onion yield by market class $\left(\mathrm{Mg} \cdot \mathrm{ha}^{-1}\right)$} & \multirow{2}{*}{\multicolumn{2}{|c|}{$\begin{array}{c}\text { Decomposition } \\
(\%) \\
\end{array}$}} \\
\hline & \multicolumn{2}{|c|}{ Total yield } & \multicolumn{2}{|c|}{ Marketable } & \multicolumn{2}{|c|}{ Colossal } & & \\
\hline & 1999 & 2000 & 1999 & 2000 & 1999 & 2000 & 1999 & 2000 \\
\hline 1. Ag Concepts & 128.6 & 147.0 & 121.6 & 135.7 & 48.8 & 59.4 & 2.0 & 4.0 \\
\hline 2. Ag Concepts & 126.8 & 148.7 & 122.3 & 141.6 & 35.4 & 65.6 & 1.3 & 2.2 \\
\hline 3. Ag Concepts & 132.0 & 149.9 & 124.1 & 143.1 & 42.1 & 64.5 & 2.6 & 2.2 \\
\hline 4. Horizon Ag. Prods. & 129.3 & 150.5 & 122.3 & 141.6 & 41.7 & 69.7 & 2.3 & 3.9 \\
\hline 5. RSA Microtech & 130.6 & 151.2 & 122.8 & 144.0 & 42.6 & 71.9 & 2.5 & 2.7 \\
\hline 6. RSA Microtech & --- & 149.9 & --- & 136.0 & --- & 55.8 & --- & 6.8 \\
\hline 7. RSA Microtech & --- & 147.4 & --- & 138.7 & --- & 62.1 & --- & 3.0 \\
\hline 8. RSA Microtech & --- & 145.2 & --- & 137.5 & --- & 57.1 & --- & 3.1 \\
\hline 9. Humi-Zyme-RX & 107.3 & --- & 101.5 & --- & 19.5 & --- & 1.6 & --- \\
\hline 10. Agri-Gro & 137.3 & 146.3 & 131.5 & 139.6 & 44.8 & 63.6 & 1.8 & 2.1 \\
\hline 11. Agri-Gro & 123.9 & 148.7 & 115.6 & 141.6 & 41.2 & 67.0 & 2.0 & 2.6 \\
\hline 12. Huma Grow & 132.4 & 144.3 & 124.1 & 135.3 & 44.4 & 52.4 & 2.2 & 3.9 \\
\hline 13. Awaken & 125.9 & 150.3 & 120.5 & 137.5 & 43.2 & 62.7 & 1.9 & 6.2 \\
\hline 14. Kozgro & 126.8 & --- & 119.6 & --- & 35.8 & --- & 1.9 & --- \\
\hline 15. Miller Chemical & --- & 153.2 & --- & 145.8 & --- & 67.4 & & 3.0 \\
\hline 16. Check & 129.5 & 154.1 & 122.5 & 146.9 & 40.8 & 65.9 & 1.9 & 2.3 \\
\hline $\mathrm{LSD}_{0.05}$ & 11.9 & NS & 12.1 & NS & 9.4 & NS & NS & NS \\
\hline
\end{tabular}

${ }^{\mathrm{N}}$ Nonsignificant.

Table 5. Onion economic performance in response to nonconventional additives.

\begin{tabular}{|c|c|c|c|c|c|c|c|}
\hline \multirow[b]{2}{*}{ Treatment } & \multirow{2}{*}{$\begin{array}{c}\text { Treatment } \\
\operatorname{cost}^{2}\end{array}$} & \multicolumn{2}{|c|}{ Production cost } & \multicolumn{2}{|c|}{ Gross returns } & \multicolumn{2}{|c|}{ Profit } \\
\hline & & 1999 & 2000 & 1999 & 2000 & 1999 & 2000 \\
\hline & - & -1 & --- & (\$/ha) & --- & --- & --- \\
\hline 1. Ag Concepts & 74.10 & 9,462 & 10,067 & 21,235 & 23,153 & 11,773 & 13,086 \\
\hline 2. Ag Concepts & 98.80 & 9,420 & 10,143 & 20,437 & 24,504 & 11,017 & 14,360 \\
\hline 3. Ag Concepts & 71.60 & 9,565 & 10,158 & 21,084 & 24,667 & 11,519 & 14,509 \\
\hline 4. Horizon Ag-Products & 84.00 & 9,491 & 10,193 & 20,847 & 24,822 & 11,356 & 14,627 \\
\hline 5. RSA Microtech & 19.80 & 9,469 & 10,151 & 20,975 & 25,383 & 11,506 & 15,235 \\
\hline 6. RSA Microtech & 27.16 & --- & 10,011 & --- & 22,968 & --- & 12,857 \\
\hline 7. RSA Microtech & 9.88 & --- & 10,012 & --- & 23,731 & --- & 13,719 \\
\hline 8. RSA Microtech & 17.28 & --- & 9,948 & --- & 23,279 & --- & 13,331 \\
\hline 9. Humi-Zyme-RX & 409.88 & 8,926 & --- & 16,163 & --- & 7,237 & --- \\
\hline 10. Agri-Gro & 123.46 & 9,798 & 10,089 & 22,444 & 23,963 & 12,647 & 13,877 \\
\hline 11. Agri-Gro & 202.47 & 9,435 & 10,254 & 19,864 & 24,526 & 10,430 & 14,274 \\
\hline 12. Huma Grow & 136.54 & 9,644 & 10,072 & 21,333 & 22,430 & 11,689 & 12,358 \\
\hline 13. Awaken & 22.22 & 9,321 & 10,123 & 20,701 & 23,802 & 11,378 & 13,679 \\
\hline 14. Kozgro & 44.44 & 9,356 & --- & 20,069 & --- & 10,714 & --- \\
\hline 15. Miller Chemical & 234.57 & --- & 10,432 & --- & 25,158 & --- & 14,276 \\
\hline 16. Check & --- & 9,412 & 10,225 & 20,765 & 25,249 & 11,353 & 15,025 \\
\hline $\mathrm{LSD}_{0.05}$ & --- & 395 & NS & 2091 & NS & 1733 & NS \\
\hline
\end{tabular}

${ }^{\mathrm{Z}}$ Includes product retail cost and application cost.

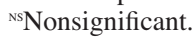

for Humaide, \$1141 for Quantum-H, and \$97 for RSAHumic acid, respectively. The granular Agri-Plus applied at $75 \mathrm{~kg} \cdot \mathrm{ha}^{-1}$ of humic acid (108 $\mathrm{kg} \cdot \mathrm{ha}^{-1}$ of product) would cost $\$ 94$ per hectare. Agri-Plus applied at $108 \mathrm{~kg} \cdot \mathrm{ha}^{-1}$ to a soil with $1.5 \%$ organic matter and 1.1 bulk density would increase the organic matter content in the top $0.3 \mathrm{~m}$ of soil by $\approx 0.15 \%$. Of the soil organic matter, $28 \%$ to $60 \%$ is comprised of humic acids (Russell, 1973). A hectare of soil 0.3 m deep with $1.5 \%$ organic matter and 1.1 bulk density would contain from 13,860 to $29,700 \mathrm{~kg} \cdot \mathrm{ha}^{-1}$ of humic acid. This indicates the difficulty of significantly increasing the soil humic acid content by applications of commercial humic acids, since large amounts are naturally present.

As alternatives to commercial humic acids, applications of compost or cover cropping, in general, can significantly increase soil organic matter and crop yields (Gaskell et al., 2000; Leary and DeFrank, 2000; Roe, 1998; Sainju and Singh, 1997). Applications of compost or cover cropping can also result in other benefits such as substituting for chemical fertilizer (Gaskell et al., 2000; Roe, 1998; Sainju and Singh, 1997) and suppressing nematodes (Ingham et al., 1999) and diseases (Davis et al., 1996; Hoitink et al., 1997), which enhance their economic efficiency. Some tillage methods can also increase soil humic acid content (McCallister and Chien, 2000).

Chen and Aviad (1990) also suggest 0.5 $\mathrm{kg} \cdot \mathrm{ha}^{-1}$ as the minimum amount of foliar applied humic acid necessary to elicit an increase in crop productivity. The only foliar applied product containing humic acid in the present study was Kozgro which supplied a total of 0.03 $\mathrm{kg} \cdot \mathrm{ha}^{-1}$ of humic acid. In other studies, humic acid increased yield of water stressed wheat when foliar applied at $0.6 \mathrm{~kg} \cdot \mathrm{ha}^{-1}$ (Xudan, 1986). Yield of extra large tomato was increased at one out of two sites by foliar applied humic acid (Castro et al., 1988). Foliar application of humic acid to olive increased shoot growth, but did not increase yield or fruit oil content (Fernandez-Escobar et al., 1996).

For the soil applied products, the products generally supplied $\mathrm{N}, \mathrm{P}, \mathrm{K}, \mathrm{S}$, and $\mathrm{Zn}$ in amounts substantially lower than the range recommended for soil application to onions based on soil tests (Table 6, Sullivan et al., 2001). The exception was Humi-Zyme-RX that supplied sulfur at $31 \mathrm{~kg} \cdot \mathrm{ha}^{-1}$ and AgriCalcium supplying calcium at $8.3 \mathrm{~kg} \cdot \mathrm{ha}^{-1}$. In both years, the soil test level for sulfate-S did not indicate a need for sulfate fertilization. The other micronutrients $(\mathrm{Mg}, \mathrm{Fe}, \mathrm{Mn}$, and $\mathrm{Cu})$ were also supplied in amounts substantially lower than the range recommended for soil application to vegetable crops (Ells, 1993; Martens and Westermann; 1991; Warncke et al., 1994). All of the foliar applied products, except High Yield, supplied micronutrients in amounts substantially lower than the recommended rates for foliar application to vegetable crops (Martens and Westermann, 1991; Vitosh et al., 1994). High Yield supplied zinc within the range recommended for correcting zinc deficiencies in crops via foliar application (Martens and Westermann, 1991). 


\begin{tabular}{|c|c|c|c|c|c|c|c|c|c|c|c|c|}
\hline \multirow[b]{2}{*}{ Treatment } & \multirow[b]{2}{*}{ Product } & \multicolumn{10}{|c|}{ Amount of nutrient added $\left(\mathrm{kg} \cdot \mathrm{ha}^{-1}\right)$} & \multirow[b]{2}{*}{ Humic acid } \\
\hline & & $\mathrm{N}$ & $\mathrm{P}$ & $\mathrm{K}$ & $\mathrm{Ca}$ & $\mathrm{S}$ & $\mathrm{Mg}$ & $\mathrm{Fe}$ & $\mathrm{Zn}$ & $\mathrm{Mn}$ & $\mathrm{Cu}$ & \\
\hline$\overline{1}$ & Jump Start 5-5-5 & 1.81 & 1.81 & 1.81 & -- & -- & --- & -- & -- & --- & --- & 0.18 \\
\hline \multirow[t]{4}{*}{2} & Humaide & --- & --- & --- & --- & --- & --- & --- & --- & --- & --- & 1.20 \\
\hline & Agzyme & --- & --- & --- & --- & --- & --- & --- & --- & --- & --- & --- \\
\hline & Kelp Treat & --- & --- & --- & --- & --- & --- & --- & --- & --- & --- & --- \\
\hline & Jump Start 5-5-5 & 1.04 & 1.04 & 1.04 & --- & --- & --- & --- & --- & --- & --- & 0.10 \\
\hline \multirow[t]{4}{*}{3} & Jump Start 5-5-5 & 0.52 & 0.52 & 0.52 & --- & --- & --- & --- & --- & --- & --- & 0.06 \\
\hline & Humaide & --- & --- & --- & --- & --- & --- & --- & --- & --- & --- & 0.59 \\
\hline & Agzyme & --- & --- & --- & --- & --- & --- & --- & --- & --- & --- & --- \\
\hline & Kelp Treat & --- & --- & --- & --- & --- & --- & --- & --- & --- & --- & --- \\
\hline \multirow[t]{2}{*}{$4(1999)$} & Agri-Plus & --- & --- & --- & --- & --- & --- & --- & --- & --- & --- & 31.4 \\
\hline & Quantum-H & --- & --- & --- & --- & --- & --- & --- & --- & --- & --- & 1.71 \\
\hline $4(2000)$ & Quantum-H & --- & --- & --- & --- & --- & --- & --- & --- & --- & --- & 5.10 \\
\hline 5 & RSA Humic acid & --- & --- & --- & --- & --- & --- & --- & --- & --- & --- & 2.40 \\
\hline \multirow[t]{2}{*}{6} & High Yield & 3.50 & 4.7 & 4.7 & --- & 0.47 & --- & 0.02 & 0.24 & 0.02 & 0.03 & --- \\
\hline & Expand & --- & --- & --- & --- & --- & --- & --- & --- & --- & 0.01 & --- \\
\hline 7 & Expand & --- & --- & --- & --- & --- & --- & --- & --- & --- & 0.01 & --- \\
\hline 8 & High Yield & 3.50 & 4.7 & 4.7 & --- & 0.47 & --- & 0.02 & 0.24 & 0.02 & 0.03 & --- \\
\hline 9 & Humi-Zyme-RX & 42.1 & 31.6 & --- & --- & 31.6 & & & & & & \\
\hline 11 & Agri-Calcium & -- & --- & --- & 8.23 & --- & --- & --- & --- & -- & --- & --- \\
\hline \multirow[t]{7}{*}{12} & Pop-up mix & 1.27 & 1.87 & 0.55 & 0.01 & 0.01 & --- & --- & --- & --- & --- & --- \\
\hline & Blend & 0.25 & --- & --- & --- & --- & --- & --- & --- & --- & --- & --- \\
\hline & Superphos & --- & 3.13 & --- & --- & --- & --- & --- & --- & --- & --- & --- \\
\hline & Sulfur & 0.06 & --- & --- & --- & 0.07 & --- & --- & --- & --- & --- & --- \\
\hline & Copper & --- & --- & --- & --- & 0.02 & --- & --- & --- & --- & 0.02 & --- \\
\hline & Calcium & 0.08 & --- & --- & 0.12 & --- & --- & --- & --- & --- & --- & --- \\
\hline & Vitol & 0.50 & 1.00 & 0.25 & --- & 0.07 & --- & --- & --- & --- & --- & --- \\
\hline 13 & Awaken & 1.03 & --- & 0.15 & --- & --- & --- & --- & --- & 0.16 & --- & --- \\
\hline \multirow[t]{2}{*}{14} & Kozgro - pre-plant & -- & --- & --- & --- & --- & --- & --- & --- & --- & --- & 0.05 \\
\hline & Kozgro - foliar & --- & --- & --- & --- & --- & --- & --- & --- & --- & --- & 0.03 \\
\hline \multirow[t]{4}{*}{15} & Microplex (seed furrow) & --- & --- & --- & --- & --- & 0.06 & 0.05 & 0.02 & 0.05 & 0.02 & --- \\
\hline & Microplex (foliar) & --- & --- & --- & --- & --- & 0.09 & 0.07 & 0.02 & 0.07 & 0.02 & --- \\
\hline & Nutrient Express & 0.9 & 9.2 & 6.05 & --- & --- & --- & --- & --- & --- & --- & --- \\
\hline & Calcium & --- & --- & --- & 0.27 & --- & --- & --- & --- & --- & --- & --- \\
\hline
\end{tabular}

Agri-Gro claims to supply N fixing bacteria and enzymes to the soil. $\mathrm{N}$ fertilization was adequate to supply onion $\mathrm{N}$ needs in these trials (Sullivan et al., 2001). Miller (1979a, 1979b) and McAllister (1987), term improbable the long-term establishment of introduced beneficial microorganisms to the soil, due to the huge amounts of microorganisms already present (to a $30 \mathrm{~cm}$ depth: $2240 \mathrm{~kg} \cdot \mathrm{ha}^{-1}$ of bacteria, actinomycetes and fungi) and to the stable soil ecosystem. Introduced microorganisms generally do not survive because they are not able to compete with the native strains.

Kelp Treat, tested as one of the products in treatments 2 and 3 , is a liquid concentrate of Norwegian kelp. Our results agree with research by Taylor et al. (1990) and Miers and Perry (1986) discussed in the introduction.

Awaken contains ammonium zinc acetate (ACA) and claims to act as a plant growth regulator to improve crop vigor. Results of the few published field tests with ACA have been inconsistent. Spilde (1998) found that wheat yield was increased by seed treatment with ACA. The lack of a response from Awaken in this study is consistent with Christenson and Bricker (1976) who found a lack of response of corn grain yield to ACA application.

In conclusion, the use of the nonconventional additives tested in this trial, under standard commercial agricultural practices on the silt loam at the Malheur Experiment Station, did not result in any crop production benefit. The low amounts of plant nutrients and humic acid supplied by the products at the rates tested cast doubt on their value in crop production. For plant nutrient supplementation, conventional soil or foliar-applied fertilizers should be considered as economical alternatives. For enhancing soil humic acid content and beneficial microorganism populations, compost applications or cover crops should be considered as economical alternatives. The possibility still exists that some of the products tested in this study or other products, applied at different rates or with different methods, or applied to poor soils or in other poor environmental conditions, might improve crop production. Users of nonconventional additives should carefully evaluate the effectiveness of individual products on small replicated areas on their own farms before investing in large scale applications.

\section{Literature Cited}

Abetz, P. 1980. Seaweed extracts: Have they a place in Australian agriculture or horticulture? J. Austral. Inst. Agr. Sci. 46:23-29.

Antognozzi, E., F. Famiani, A. Palliotti, and A. Tombesi. 1993. Effects of CPPU (cytokinin) on kiwifruit productivity. Acta Hort. 329: $150-152$.

Ayuso, M., J.L. Moreno, T. Hernandez, and C. Garcia. 1997. Characterization and evaluation of humic acids extracted from urban waste as liquid fertilizers. J. Sci. Food Agr. 75:481-488.

Boyhan, G.E., W.M. Randle, A.C. Purvis, P.M. Lewis, R.L. Torrance, D.E. Curry, and D.O. Linton. 2001. Evaluation of growth stimulants on short-day onions. HortTechnology. 11:38-42.

Brownell, J.R., G. Nordstrom, J. Marihart, and G Jorgensen. 1987. Crop responses from two new leonardite extracts. The Sci. of the Total Environ.
62:491-499.

Castro, B.F., S.J. Locascio, and S.M. Olson. 1988. Tomato response to foliar nutrient and biostimulant applications. Proc. Fla. State Hort. Soc. 101:350-353.

Chen, Y. and T. Aviad. 1990. Effects of humic substances on plant growth, p. 161-186. In: P. MacCarthy, C.E. Clapp, R.L. Malcolm, and P.R. Bloom (eds.). Humic substances in soil and crop sciences: selected readings. Amer. Soc. of Agron. and Soil Sci. Soc. Amer., Madison, Wisc.

Christenson, D.R. and C. Bricker. 1976. The effect of time and rate of Amoco agricultural crop additive (ACA) on yield and protein content of corn grain. In: Compendium of research reports on use of non-traditional materials for crop production. NCR-103 Committee. Coop. Ext. Serv., Iowa State Univ.

Crawford, J.H., T.L. Senn, and G.E. Stembridge. 1969. The influence of humic acid fractions on sprout production and yield of the carogold sweet potato. South Carolina Agr. Expt. Sta. Tech. Bul. 1029:1-16.

Davis, J.R., O.C. Huisman, D.T. Westermann, S.L. Hafez, D.O. Everson, L.H. Sorensen, and A.T. Schneider. 1996. Effects of green manures on Verticillium wilt of potato. Phytopathology 86: 444-453.

Ells, J.E. 1993. Vegetable fertilizer guide no. 0.509. Colorado State Univ. Coop. Ext.

Eris, A., H.O. Sivritepe, and N. Sivritepe. 1995. The effects of seaweed (Ascophyllum nodosum) extract on yield and quality criteria in peppers. Acta Hort. 412:185-192.

Fernandez-Escobar, R., M. Benlloch, D. Barranco, A. Duenas, and J.A. Guterrez-Ganan. 1996. Response of olive trees to foliar application of humic substances extracted from leonardite. Scientia Hort. 66:191-200.

Flaishman, M.E., A. Shargal, R. Stern. 2001. The 
synthetic cytokinin CPPU increases fruit size and yield of 'Spadona' and 'Costia' pear ( $P y$ rus communis L.) J. Hort. Sci. Biotech. 76 : 145-149.

Gaskell, M., B. Fouche, S. Koike, T. Lanini, J. Mitchell, and R. Smith. 2000. Organic vegetable production in California: Science and practice. HortTechnology 10:699-713.

Hedin, P.A. and J.C. McCarty, Jr. 1994. Multiyear study of the effects of kinetin and other plant growth hormones on yield, agronomic traits, and allelochemicals of cotton. J. Agr. and Food Chem. 42:2305-2307.

Hoitink, H.A.J., A.G. Stone, and D.Y. Han. 1997. Suppression of plant diseases by composts. HortScience 32:184-187.

Ingham, R., R. Dick, and R. Sattell. 1999. Columbia root-knot nematode control in potato using crop rotations and cover crops. Oregon State Univ. Ext. Publ. no. EM 8740.

Kephart, K. 1993. Nonconventional soil additive listing. Missouri Univ. Agron. Tech. Rpt. V. 11 No. 1.

Lawless, J.R., H.D. Sunderman, F.L. Lamm, and L.D. Robertson. 1984. Report of Research Results, Supplement 1. In: Compendium of research reports on use of non-traditional materials for crop production. NCR-103 Committee. Coop. Ext. Serv. Iowa State Univ.

Leary, J. and J. DeFrank. 2000. Living mulches for organic farming systems. HortTechnology 10:692-698.

Ma, Q., N. Longnecker, and C. Atkins. 1998. Exogenous cytokinin and nitrogen do not increase grain yield in narrow-leafed lupins. Crop Sci. 38:717-721.

Martens, D.C. and D.T. Westermann. 1991 Fertilizer applications for correcting micronutrient deficiencies, p. 549-592. In: J.J. Mortvedt, F.R. Cox, L.M. Shuman, and R.M. Welch (eds.). Micronutrients in agriculture. 2nd ed. Soil Sci. Soc. Amer. book series \#4, Madison, Wisc.

Mcallister, J. 1987. A practical guide to novel soil amendments. Rodale Res. Ctr., Rodale Press.
McCallister, D.L. and W.L. Chien. 2000. Organic carbon quantity and forms as influenced by tillage and cropping sequence. Commun. Soil Sci. Plant Anal. 31:465-479.

Miers, D.J. and M.W.Perry. 1986. Organic materials applied as seed treatments or foliar sprays fail to increase grain yield of wheat. Austral. J. Expt. Agr. 26:367-373.

Miller, R.H. 1979a. Microbial soil amendments from the biologist's point of view. The New Farm May/June:25-28.

Miller, R.H. 1979b. Ecological factors which influence the success of microbial fertilizers or activators. Dev. in Ind. Microbiol. 20: $335-342$.

Nemec, S. and O. Lee. 1992. Effects of preplant deep tillage of soil amendments on soil mineral analysis, citrus growth, production and tree health. Soil and Tillage Res. 23:317-331.

Oosterhuis, D. and W.C. Robertson. 2000. The use of plant growth regulators and other additives in cotton production. Proc. of the 2000 Cotton Res. Mtg. Arkansas Agr. Expt. Sta. Spec. Rpt. 198.

Reynolds, A.G., D.A. Wardle, C. Zurowski, and N.E. Looney. 1992. Phenylureas CPPU and Thidiazuron affect yield components, fruit composition, and storage potential of four seedless grape selections. J. Amer. Soc. Hort. Sci. 117:85-89.

Roe, N.E. 1998. Compost utilization for vegetable and fruit crops. HortScience 33:934-937.

Rowberry, R.G. and G.H. Collin. 1977. The effects of humic acid derivatives on the yield and quality of Kennebec and Sebago potatoes. Amer. Pot. J. 54:607-609.

Russell, E.W. 1973. Soil conditions and plant growth. 10th ed. Longman, New York.

Sanders, D.C., J.A. Ricotta, and L. Hodges. 1990. Improvement of carrot stands with plant biostimulants and fluid drilling. HortScience 25: 181-183.

Sainju, U.M. and B.P. Singh. 1997. Winter cover crops for sustainable agricultural systems: influence on soil properties, water quality, and crop yields. HortScience 32:21-28.
Seyedbagheri, M. and M. Thornton. 1995. Effects of humic substances on potato yield and quality in field trials. Proc. Intl. Conf. on Humic Substances in the Environ., Atlanta, Ga.

Shock, C.C., E.B.G. Feibert, and L.D. Saunders 1998. Onion yield and quality affected by soil water potential as irrigation threshold. HortScience 33:1188-1191.

Shock, C.C., J.K. Ishida, E.P. Eldredge, and M. Seddigh. 2000. Yield of yellow onion cultivars in eastern Oregon and southwestern Idaho. HortTechnology 10:613-620.

Spilde, L.A. 1998. Agronomic response of hard red spring wheat with ACA seed application. North Dakota Agr. Res. Fall 1998.

Sullivan, D.M., B.D. Brown, C.C. Shock, D.A Horneck, R.G. Stevens, G.Q. Pelter, and E.B.G. Feibert. 2001. Nutrient management for onions in the Pacific northwest. Pacific Northwest Ext. Publ. 546.

Taylor, J.S., K.N. Harker, J.M. Robertson, and K.R. Foster. 1990. The effect of a seaweed extract containing cytokinin on the growth and yield of barley. Can. J. Plant Sci. 70:1163-1167.

Tomkins, J.P. and M.H. Hall. 1991. Stimulation of alfalfa bud and shoot development with cytokinins. Agron. J. 83:577-581.

Vasudevan, S.N., K. Virupakshappa, N. Venugopal, and S. Bhaskar. 1997. Response of sunflower (Helianthus annuus) to phosphorus, sulphur, micronutrients, and humic acid under irrigated condition on red sandy-loam soil. Indian J. Agr. Sci. 67:110-112.

Vitosh, M.L., D.D. Warncke, and R.E. Lucas. 1994 Secondary and micronutrients for vegetables and field crops. Michigan State Univ. Ext. Bul. E-486.

Warncke, D.D., D.R. Christenson, L.W. Jacobs, M.L. Vitosh, and B.H. Zandstra. 1994. Fertilizer recommendations for vegetable crops in Michigan. Michigan State Univ. Ext. Veg. Bul. 55092001.

Xudan, Xu. 1986. The effect of foliar application of fulvic acid on water use, nutrient uptake and yield of wheat. Austral. J. Agr. Res. 37: 343-350. 